\title{
Strategi Pemasaran Produk Khas Daerah oleh Dinas Perindustrian Perdagangan Koperasi dan UKM Kota Palu dalam Perspektif Ekonomi Syariah
}

\author{
Muh. Rif'an ${ }^{1 *}$ Sitti Aisyah ${ }^{2}$, Fatma Fatma ${ }^{3}$, Ferdiawan Ferdiawan ${ }^{3}$ \\ ${ }^{1}$ Jurusan Ekonomi Syariah, Fakultas Ekonomi dan Bisnis Islam, IAIN Palu \\ 2 Jurusan Ekonomi Syariah, Fakultas Ekonomi dan Bisnis Islam, IAIN Palu \\ ${ }^{3}$ Jurusan Ekonomi Syariah, Fakultas Ekonomi dan Bisnis Islam, IAIN Palu
}

ABSTRAK

Tujuan penelitian ini adalah untuk memahami bagaimana strategi pemasaran produk khas daerah oleh Dinas Perindustrian, Perdagangan, Koperasi dan UKM Kota Palu (Dalam perspektif ekonomi syariah) dan Untuk memahami kendala-kendala apa saja yang dihadapi oleh Dinas Perindustrian, Perdagangan, Koperasi dan UKM Kota Palu dalam memasarkan produk khas daerah Kota Palu. Metode yang digunakan dalam penelitian ini adalah metode deskriftif kualitatif dengan teknik pengumpulan data yaitu wawancara, observasi, verivikasi guna mendapatkan data yang benar-benar valid dan dapat di pertanggungjawabkan. Hasil penelitian ini menunjukkan bahwa strategi pemasaran produk khas daerah oleh Dinas Perindustrian, Perdagangan, Koperasi dan UKM Kota Palu terbagi atas dua yaitu promosi dan penjualan adapun yang termasuk dalam promosi yaitu promosi yang di lakukan melalalui media elektronik dan juga mempromosikan melaluli acara-acara besar daerah yang di adakan oleh Dinas Perindustrian, Perdagangan,Koperasi dan UKM Kota Palu. Kendala yang dihadapi oleh Dinas Perindustrian, Perdagangan, Koperasi dan UKM Kota Palu dalam memasarkan produk khas daerah Kota Palu (Dalam perspektif ekonomi syariah), adalah belum mempunyai outlet sendiri yang di sediakan oleh pemerintah.
INFORMASI ARTIKEL

Kata kunci:

Pemasaran, produk khas daerah, strategy, ekonomi Islam 


\section{PENDAHULUAN}

Perkembangan dunia bisnis saat ini semakin pesat, sehingga persaingan usaha juga semakin ketat, hal ini disebabkan karena kemajuan ilmu pengetahuan dan teknologi. Kondisi ini mendorong para pelaku bisnis untuk memproduksi barang atau jasa, para pelaku bisnis juga berkopetensi agar bisnisnya tetap hidup, tumbuh, dan berkembang. Pernyataan ini tentunya sangat erat kaitanya dengan tujuan usaha. Tujuan usaha pada dasarnya untung mencari laba atau keuntungan yang maksimal dengan memanfaatkan sumber daya dan kemampuan yang tersedia, sehingga dalam upaya dalam memncapai satu tujuan tersebut pelaku bisnis harus memperkenalkan produk yang dihasilkan kepada konsumen melalui kegiatan pemasaran dengan meningkatkan promosi, kualitas, distribusi serta pelayanan untuk memberikan kepuasan pada konsumen.

Pemasaran merupakan salah satu dari kegiatan-kegiatan pokok yang dilakukan oleh pelaku bisnis untuk melangsungkan kelangsungan hidupnya, berkembang, dan mendapatkan laba. Strategi pemasaran adalah faktor yang sangat penting dalam mempromosikan produk-produk usahanya. Pelaku bisnis harus mengidentifikasi kebutuhan konsumen untuk mengetahui informasi pasar yang ada. Data yang tersedia akan menjadi sumber informasi penting untuk menyusun strategi yang tepat.

Secara umum, penentuaan strategi yang tepat bagi pelaku bisnis yang dimulai dengan mengenali peluang dan ancaman yang terkandung dalam lingkungan eksternal serta memahami kekuatan dan kelemahan pada aspek internal usahanya. Strategi pemasaran mempunyai peranan yang sangat penting untuk keberhasilan usahanya. Di samping itu strategi pemasaran yang ditetapkan harus ditinjau dan dikembangkan sesuai dengan perkembangan pasar dan lingkungan pasar tersebut. Dengan demikian, perusahaan mampu bersaing dan mencapai tujuan secara efektif dan efisien.

Saat ini sering dijumpai strategi pemasaran yang tidak etis, curang dan tidak professional. Kiranya perlu dikaji bagaimana akhlak dalam kegiatan ekonomi secara keseluruhan atau lebih khusus lagi akhlak dalam pemasaran kepada masyarakat dari sudut pandangan ekonomi syariah. Kegiatan pemasaran seharusnya dikembalikan pada karakteristik yang sebenarnya yakni religius, beretika, realistis dan menjunjung tinggi nilai-nilai kemanusiaan dan inilah konsep terbaik strategi pemasaran untuk hari ini dan masa depan.

Prinsip Strategi pemasaran yang berakhlak seharusnya di terapkan. Apalagi nilai-nilai akhlak, moral dan etika sudah diabaikan. Sangat dikhawatirkan bila 
menjadi kultur masyarakat. Perspektif pemasaran dalam ekonomi syariah adalah ekonomi Rabbani (divinity), realistis, humanis dan keseimbangan. ${ }^{1}$ Inilah yang membedakan sistem ekonomi syariah dengan sistem ekonomi konvensional. Strategi pemasaran ekonomi syariah meyakini, perbuatan seseorang akan dimintai pertanggung jawabannya kelak. Selain itu, strategi pemasaran ekonomi syariah mengutamakan nilai-nilai akhlak dan etika moral dalam pelaksanaannya. Oleh karena itu, strategi pemasaran ekonomi syariah menjadi penting bagi para tenaga pemasaran untuk melakukan penetrasi pasar.

Kota Palu merupakan salah satu daerah yang memiliki potensi dan daya saing yang kuat melalui produk-produk khas unggulan daerah terbaiknya seperti industri anyaman rotan. Pemerintah Kota Palu melalui Dinas Perindustrian, Perdagangan, Koperasi dan UKM terus berupaya mengoptimalkan potensi daerah melalui pembinaan industri kecil dan menengah (IKM) melalui produkproduk unggulan khas daerah terbaiknya, agar dapat terus tumbuh dan berkembang menjadi kegiatan usaha yang menguntungkan, sehingga dapat mendorong peningkatan kesejahteraan masyarakat. Perkembangan dan pertumbuhan produkproduk unggulan khas daerah Kota Palu

\footnotetext{
${ }^{1}$ Hermawan Kartajaya dan Muhammad Syakir Sula: Syariah Marketing, MarkPlus \& Co, (Bandung : Mizan Pustaka, 2006), h. 63
}

dewasa ini, tidak terlepas dari strategi pemasaran yang dijalankan oleh Pemerintah Kota Palu melalui Dinas Perindustrian Perdagangan dan Koperasi yang berkelanjutan hingga saat ini. Semuanya dilaksanakan dengan satu tekad dan semangat agar pertumbuhan produkproduk unggulan khas daerah Kota Palu dapat terus berkembang secara sehat dan kuat sehingga dapat menjadi bagian integral dari seluruh kegiatan industri, dan mampu memberikan kontribusi signifikan dalam memperkuat perekonomian Kota Palu karena strategi pemasaran yang tepat serta terarah akan menjadi kunci kesuksesan bagi pemasaran suatu produk.

\section{TINJAUAN PUSTAKA}

\subsection{Penelitian Terdahulu}

Penelitian terdahulu dengan judul Peran Dinas Perindustrian dan Perdagangan dalam pemberdayaan pengrajin kerajinan perak sebagai sebagai produk unggulan Daerah (Studi pada Dinas Perindustrian dan Perdagangan Kabupaten Mojokerto). Oleh Candra Arysta Putra Pradana, Nim : 13710134004. Jurusan Administrasi Publik, Fakultas Ilmu Administrasi, Universitas Brawijaya, Malang. Tahun 2011 memberikan kesimpulan bahwa Dinas Perindustrian dan Perdagangan berusaha melakukan perannya untuk menumbuhkan kegiatan masyarakat tersebut. Dalam hal ini 
Dinas Perindustrian dan Perdagangan Kabupaten Mojokerto melakukan pemberdayaan kepada pengrajin kerajinan perak melalui programnya yakni dengan mengadakan pelatihan dan pembinaan serta meringankan izin pendirian usaha demi membuat kerajinan perak menjadi suatu produk unggulan daerah.

Peran Dinas Perindustrian, Perdagangan, Koperasi dan UKM dalam mempromosikan produk Industri Kecil Menengah di YOGYAKARTA. Oleh : Tika Nur Arifah , Nim : 12810134003 Program Studi Manajemen Pemasaran, Fakultas Ekonomi Universitas Negeri Yogyakarta. Tahun 2013 memberikan kesimpulan bahwa:

1. Dinas Perindustrian, Perdagangan, Koperasi \& UKM mempunyai peranan dalam mempromosikan produk Industri Kecil Menengah (IKM) melalui berbagai jenis pameran.

2. Industri kecil yang dibina oleh Disperindagkop \& UKM umumnya ditangani di unit bidang industri. Salah satu pameran yang pernah dilakukan adalah Pameran pengembangan industri kreatif di Malioboro Mall Yogyakarta 2014

\subsection{Pemasaran Dalam Perspektif Ekonomi} Syariah
Pemasaran atau dalam bahasa Inggrisnya lebih dikenal dengan sebutan marketing, Istilah tersebut sudah sangat dikenal di kalangan pebisnis. Pemasaran mempunyai peran penting dalam peta bisnis suatu perusahaan dan berkontribusi terhadap strategi produk, strategi harga, strategi penyaluran/distribusi, dan strategi promosi. Definisi Pemasaran secara umum menurut Philip Kotler seorang guru pemasaran dunia, adalah sebagai berikut : Pemasaran (marketing) adalah kegiatan manusia yang diarahkan untuk memenuhi kebutuhan dan keinginan melalui proses pertukaran. ${ }^{2}$ Sedangkan Pemasaran dalam pandangan syariah merupakan suatu penerapan disiplin strategis yang sesuai dengan nilai dan prinsip syariah. $^{3}$

Hermawan Kartajaya dan Muhammad Syakir Sula memberikan definisi untuk pemasaran syariah adalah sebagai berikut :

Pemasaran syariah adalah sebuah disiplin strategis yang mengarahkan proses penciptaan, penawaran, dan perubahan values dari satu inisiator kepada stakeholdernya, yang dalam keseluruhan prosesnya sesuai dengan akad dan prinsip-prinsip muamalah Islami. $^{4}$

\footnotetext{
${ }^{2}$ Philip Kotler, dan Gary Armstrong, Prinsipprinsip pemasaran, (Jakarta : Erlangga, 2005), h. 2

3 Ibid, 3

${ }^{4}$ Hermawan Kartajaya dan Muhammad Syakir Sula: Syariah Marketing, MarkPlus \& Co, (Bandung : Mizan Pustaka, 2006), h. 67
} 
Pemasaran merupakan ruh dari sebuah institusi bisnis. Semua orang yang bekerja dalam institusi tersebut adalah marketer yang membawa intergritas, identitas, dan image perusahaan. Sebuah institusi yang menjalankan. Pemasaran syariah adalah perusahaan yang tidak berhubungan dengan bisnis yang mengandung unsur-unsur yang dilarang menurut syariah, yaitu bisnis judi, riba, dan produk-produk haram. Namun, walaupun bisnis perusahaan tersebut tidak berhubungan dengan kegiatan bisnis yang diharamkan, terkadang taktik yang digunakan dalam memasarkan produkproduk mereka masih menggunakan caracara yang diharamkan dan tidak etis. ${ }^{5}$

Pemasar adalah garis depan suatu bisnis, mereka adalah orang-orang yang bertemu langsung dengan konsumen sehingga setiap tindakan dan ucapannya berarti menunjukkan citra dari barang dan perusahaan.

Ada dua tujuan utama dari pemasaran syariah yaitu :

\section{Memarketingkan syariah}

Memarketingkan syariah artinya perusahaan yang pengelolaannya berlandaskan syariah Islam dituntut untuk bisa bekerja dan bersikap profesional dalam dunia bisnis. Juga dibutuhkan suatu program pemasaran yang komprehensif mengenai nilai dan value dari produk-produk syariah

${ }^{5}$ Ibid, h. 68 agar dapat diterima dengan baik, sehingga tingkat pemahaman masyarakat yang masih memandang rendah terhadap diferensiasi yang ditawarkan oleh perusahaan yang berbasiskan syariah.

\section{Mensyariahkan Marketing}

Mensyariahkan Marketing artinya dengan mensyariahkan marketing, sebuah perusahaan tidak akan serta merta menjalankan bisnisnya demi keuntungan pribadi saja tetapi juga karena usaha untuk menciptakan dan menawarkan bahkan dapat merubah suatu values kepada para stakeholder utamanya (Allah swt, konsumen, karyawan, pemegang saham). Sehingga perusahaan tersebut dapat menjaga keseimbangan laju bisnisnya. ${ }^{6}$

Semua aktivitas kehidupan perlu dilakukan berdasarkan strategi yang baik. Islam agama yang memberikan sintesis dan strategi yang dapat direalisasikan melalui rangsangan dan bimbingan. Strategi tidak lain memanfaatkan karunia Allah secara sistematik untuk mencapai tujuan tertentu, dengan memperhatikan kebutuhan masyarakat dan nilai kehidupan yang berubah-ubah. Dalam arti lebih luas, strategi menyangkut persiapan menyusun rancangan untuk setiap kegiatan ekonomi. Konsep modern tentang strategi yang harus dipahami dalam arti terbatas, diakui dalam Islam. Karena strategi seperti itu mencakup ${ }^{6} /$ bid, h. 68 
pemanfaatan sumber yang disediakan oleh Allah Swt. dengan sebaik-baiknya untuk kehidupan dan kesenangan manusia.

Di samping itu, pelaksanaan strategi pemasaran dalam Islam, juga tergantung pada prinsip syarikat (kerjasama) yang telah diakui secara universal. Hal ini berarti pelaksanaan perencanaan dilaksanakan melalui partisipasi sektor pemerintah dan swasta atas dasar kemitraan. Yakni terlaksana melalui prinsip abadi mudharabah, yakni tenaga kerja dan pemilik modal dapat disatukan sebagai mitra. ${ }^{7}$ Dalam arti, dengan mempraktekkan prinsip mudharabah dan dengan mengkombinasikan berbagai unit produksi, proyek industri, perdagangan dan pertanian dalam kerangka perencanaan dapat diterapkan atas dasar prinsip tersebut. Pendapatan yang dihasilkan oleh usaha seperti itu dapat dibagi secara sebanding setelah dikurangi segala pengeluaran yang sah.

Dalam sistem strategi pemasaran ekonomi syariah, kemungkinan rugi sangat kecil karena merupakan hasil kerjasama antara sektor pemerintahan dan swasta. Investasi yang sehat akan mendorong kelancaran arus kemajuan ekonomi menjadi lebih banyak. Dalam kegiatan pemasaran, tentu lebih dahulu menyusun perencanaan

\footnotetext{
${ }^{7}$ Hermawati Ancella Anitawati, Manajemen pemasaran , (Jakarta : salemba empat, 1995), h. 37
}

strategis untuk memberi arah terhadap kegiatan perusahaan yang menyeluruh, yang harus didukung, rencana pelaksanaan lebih rinci di bidang-bidang kegiatan perusahaan. Dalam Syariah Islam, bukanlah suatu larangan bila seorang hamba mempunyai keinginan untuk berhasil dalam usahanya. Namun dengan syarat, keinginan itu tidak bertentangan dengan ajaran (syariat) Islam.

Saat ini semakin banyak masyarakat dunia yang sadar tentang kegiatan bermuamalah secara ekonomi syariah. Salah satu buktinya adalah pesatnya perkembangan minat masyarakat dunia terhadap ekonomi syriah dalam dua dekade terakhir, Indonesia sebagai negara berpenduduk Muslim terbesar di dunia juga mengalami hal yang sama. Hal ini dibuktikan dengan semakin bermunculan berbagai produk syariah (Islam). Saat ini perkembangan yang menyolok adalah produk yang bersentuhan dengan bidang lembaga keuangan. Namun pesatnya perkembangan produk ekonomi syyariah belum bisa diimbangi oleh pesatnya perkembangan dari sisi keilmuan yang lebih luas. Jika hal ini terjadi secara terusmenerus, akan terjadi ketimpangan perkembangan ekonomi Syariah ke depan. Untuk itu pengembangan ekonomi syariah dari sisi keilmuan menjadi hal mutlak, untuk menjadi penyeimbang pesatnya perkembangan yang terjadi saat ini. 
Pemasaran adalah suatu aktivitas yang selalu dikaitkan dengan perdagangan. Jika meneladani Rasulullah saat melakukan perdagangan, maka beliau sangat mengedepankan adab dan etika dagang yang luar biasa. Etika dan adab perdagangan inilah yang dapat disebut sebagai strategi dalam berdagang. Oleh karena itu, Seykh Sayyid Nada membeberkan sejumlah adab yang harus dijunjung pedagang muslim dalam menjalankan aktivitas jual-beli, berdasarkan hadis-hadis Rasulullah, sebagai berikut:

1. Tidak menjual sesuatu yang haram. Umat Islam dilarang menjual sesuatu yang haram seperti minuman keras dan memabukkan, narkotika dan barangbarang yang diharamkan Allah Swt. Hasil penjualan barang-barang itu hukumnya haram dan kotor.

2. Tidak melakukan sistem perdagangan terlarang. Contohnya menjual yang bukan miliknya. Selain itu Islam juga melarang umatnya menjual buah-buahan yang belum jelas hasilnya serta sistem perdagangan terlarang lainnya.

3. Tidak terlalu banyak mengambil untung.

4. Tidak membiasakan bersumpah ketika berdagang.

5. Tidak berbohong ketika berdagang. Salah satu perbuatan berbohong adalah menjual barang yang cacat namun tidak diberitahukan kepada pembelinya.
6. Pemaaf, mempermudah dan lemah lembut dalam berjual beli.

7. Tidak boleh memakan dan memonopoli barang dagangan tertentu. ${ }^{8}$

Konsep Pemasaran ekonomi Syariah yang ditawarkan oleh Hermawan dam Muhammad Syakir Sula diantaranya adalah :

1. Syariah Marketing Strategy, untuk memenangkan mind-share, dapat dilakukan pemetaan pasar berdasarkan pertumbuhan pasar, keunggulan kompetitif dan situasi persaingan. Dari pemetaan potensi pasar sebelumnya, dapat dilihat bahwa pasar rasional atau pasar mengambang merupakan pasar yang sangat besar. Para pebisnis harus dapat membidik pasar rasional yang sangat potensial tersebut. Setelah itu mereka perlu melakukan positioning sebagai perusahaan yang mampu meraih mindshare.

2. Syariah Marketing Tactic, untuk memenangkan market-share. Ketika positioning pebisnis syariah di benak pasar rasional telah kuat, mereka harus melakukan diferensiasi yang mencakup apa yang ditawarkan (content), bagaimana menawarkan (context) dan apa infrastruktur dalam menawarkannya. Langkah selanjutnya para marketer perlu menerapkan diferensiasi secara kreatif

\footnotetext{
${ }^{8} \mathrm{Htp} /$ www. Seykh Sayyid Nada, Adab Pedagang Muslim dalam Menjalankan Aktivitas JualBeli. Di Akses Pada Tanggal 24 Mei 2016
} 
dan inovatif dengan menggunakan marketing mix (price, product, place and promotion). Hal-hal yang perlu dipersiapkan juga, bagaimana pebisnis melakukan selling dalammeningkatkan hubungan dengan pelanggan sehingga mampu menghasilkan keuntungan finansial.

3. Syariah Marketing Value, untuk memenangkan heart-share (kecintaan pelanggan terhadap produk). Terakhir, semua strategi dan taktik yang sudah dirancang akan berjalan optimal bila disertai dengan peningkatan value dari produk atau jasa yang dijual. Peningkatan value di sini berarti bagaimana kita mampu membangun brand yang kuat, memberikan service yang membuat pelanggan loyal, dan mampu menjalankan proses yang sesuai dengan kepuasan pelanggan.Dalam Syariah Marketing Value, brand merupakan nama baik yang menjadi identitas seseorang atau perusahaan. Contohnya Nabi Muhammad saw yang terekam kuat di pikiran semua orang bahwa beliau adalah seorang AlAmin. Brand itu menjadikan Nabi Muhammad lebih mudah untuk mengkomunikasikan produknya, karena semua orang telahmempercayai semua kata-katanya.

4. Syariah Marketing Scorecard, untuk menciptakan keseimbangan value kepada para stakeholders. Tiga stakeholders utama dari suatu perusahaan adalah people, customers, dan shareholders. Ketiga stakeholders tersebut sangat penting karena mereka adalah orangorang yang sangat berperan dalam menjalankan suatu usaha. Di dalam pasar komersial (commercial market), perusahaan harus bisa mengakuisisi dan meretensi pelanggannya. Di dalam pasar kompetensi (competency market), perusahaan harus bisa memilih dan mempertahankan orang-orang yang tepat. Sedangkan di dalam pasar modal (capital market), perusahaan harus bisa mendapatkan dan menjaga para pemegang saham yang tepat. Untuk menjaga keseimbangan ini, perusahaan harus bisa menciptakan value yang unggul bagi ketiga stakeholders utama tersebut dengan ukuran dan bobot yang sama.

5. Syariah Marketing Enterprise, untuk menciptakan sebuah inspirasi (inspiration). Setiap perusahaan, layaknya manusia, haruslah memiliki impian. Inspirasi tentang impian yang hendak dicapai inilah yang akan membimbing manusia, dan juga perusahaan, sepanjang perjalanannya. sebuah perusahaan harus mampu menggabungkan antara idealisme dan pragmatisme. Perusahaan harus mampu idealistik dan sekaligus 
pragmatis, dan mampu mengimplementasikan kedua hal ini sekaligus dan secara simultan. ${ }^{9}$

Praktek bisnis dan pemasaran tengah mengalami pergeseran dan mengalami transformasi, dari level intelektual (rasional), ke emosional, dan pada akhirnya ke level spiritual. Pada level intelektual, pemasar akan menyikapi pemasaran secara fungsional-teknikal dengan menggunakan sejumlah tools pemasaran, seperti segmentasi pasar, bauran pemasaran (marketing mix), targeting, dan lain sebagainya.

Di level emosional, kemampuan pemasar dalam memahami emosi dan perasaan pelanggan menjadi penting. Jika di level intelektual pemasaran layaknya sebuah "robot", di level emosional menjadi seperti "manusia" yang berperasaan dan empatik. Di level spiritual ini, pemasaran sudah disikapi sebagai "bisikan nurani"dan "panggilan jiwa” (calling). Dalam konteks ini, Praktek pemasaran dikembalikan kepada fungsinya yang hakiki dan dijalankan dengan moralitas yang kental.

Prinsip- prinsip kejujuran, empati, cinta, dan kepedulian terhadap sesama menjadi dominan. Paradigma baru muncul dalam pemasaran, dilandasi oleh kebutuhan yang paling pokok, yang paling dasar, yaitu

${ }^{9}$ Kertajaya, Hermawan dan M. Syakir Sula, $O p$, cit, h. 134-137 kejujuran, moral, dan etika dalam bisnis. Inilah spiritual marketing. Hal ini menjadikan spiritual marketing merupakan tingkatan tertinggi dalam konsep pemasaran ekonomi syariah. Spiritual marketing menjadi jiwa bagi bisnis yang berprinsipkan syariah. ${ }^{10}$

Seorang pengusaha dalam pandangan etika ekonomi Syariah bukan sekedar mencari keuntungan, melainkan juga keberkahan, yaitu kemantapan dari usaha itu dengan memperoleh keuntungan yang wajar dan diridloi oleh Allah swt. Ini berarti yang harus diraih oleh seorang pedagang dalam melakukan bisnis tidak sebatas keuntungan materiil (bendawi), tetapi yang penting lagi adalah keuntungan immaterial (spiritual). ${ }^{11}$

Ada empat karakteristik yang terdapat pada pemasaran syariah:

\section{Ketuhanan (Rabbaniyyah)}

Salah satu ciri khas pemasaran syariah adalah sifatnya yang religius. Jiwa seorang syariah marketer meyakini bahwa hukumhukum syari'at yang bersifat ketuhanan merupakan hukum yang paling adil, sehingga akan mematuhinya dalam setiap aktivitas pemasaran yang dilakukan. Dalam setiap langkah, aktivitas dan kegiatan yang dilakukan harus selalu menginduk kepada

\footnotetext{
${ }^{10} \mathrm{M}$. Ismail Yusanto dan M.K. Widjajakusuma, Op, cit, h. 124

${ }^{11}$ /bid, 125
} 
syariat Islam. Seorang syariah marketer meskipun ia tidak mampu melihat Allah, ia akan selalu merasa bahwa Allah senantiasa mengawasinya. Sehingga ia akan mampu untuk menghindar dari segala macam perbuatan yang menyebabkan orang lain tertipu atas produk-produk yang dijualnya. Sebab seorang syariah marketer akan selalu merasa bahwa setiap perbuatan yang dilakukan akan dihisab.

\section{Etis (Akhlaqiyyah)}

Keistimewaan lain dari syariah marketer adalah mengedepankan masalah akhlak dalam seluruh aspek kegiatannya. Pemasaran syariah adalah konsep pemasaran yang sangat mengedepankan nilai-nilai moral dan etika tanpa peduli dari agama apapun, karena hal ini bersifat universal.

\section{Realistis (Al-waqi'iyyah)}

Pemasaran syariah bukanlah konsep yang eksklusif, fanatis, anti modernitas, dan kaku, melainkan konsep pemasaran yang fleksibel. Syariah marketer bukanlah berarti para pemasar itu harus berpenampilan ala bangsa Arab dan mengharamkan dasi. Namun syariah marketer haruslah tetap berpenampilan bersih, rapi, dan bersahaja apapun model atau gaya berpakaian yang dikenakan.

4. Humanistis (Insaniyyah)
Keistimewaan yang lain adalah sifatnya yang humanistis universal. Pengertian humanistis adalah bahwa syariah diciptakan untuk manusia agar derajatnya terangkat, sifat kemanusiaannya terjaga dan terpelihara, serta sifat-sifat kehewanannya dapat terkekang dengan panduan syariah. Syariah Islam adalah syariah humanistis, diciptakan untuk manusia sesuai dengan kapasitasnya tanpa memperdulikan ras, warna kulit, kebangsaan, dan status. Sehingga pemasaran syariah bersifat universal. $^{12}$

Prinsip-Prinsip Pemasaran dalam Perspektif Ekonomi Syariah

Dalam bukunya Hermawan Kertajaya dan Sakir Sula mengatakan bahwa untuk mengkonsep sebuah marketing syariah harus mengetahui tentang prinsip-prinsip marketing syariah. Menurut mereka ada 17 prinsip marketing syariah, yaitu:

\section{a. Change}

Perubahan adalah suatu hal yang pasti akan terjadi. Oleh karena itu, perubahan perlu disikapi dengan cermat. Kekuatan perubahan terdiri dari lima unsur: perubahan tekhnologi, perubahan politik legal, perubahan sosialkultural, perubahan

\footnotetext{
${ }^{12}$ Kertajaya, Hermawan dan M. Syakir Sula, Op, cit, h. 151-15
} 
ekonomi, dan perubahan pasar. Dalam hal ini lebih menekankan pada dampak perubahan tekhnologi. Akar terjadinya segala perubahan - baik perubahan sosial, politik, ataupun ekonomi - adalah karena adanya inovasi terus-menerus di bidang tekhnologi.

\section{b. Competitor}

Dalam menjalankan syariah marketing, perusahaan harus memperhatikan cara mereka menghadapi persaingan usaha yang serba-dinamis. Jadi ketika persaingan usaha yang dihadapi semakin ketat dan kadang bersifat kotor, perusahaan harus mempunyai kekuatan moral untuk tidak terpengaruh oleh permainan bisnis seperti itu.

\section{c. Customer}

Di era globalisasi seperti sekarang, masyarakat menjalani kehidupannya secara paradoks. Paradoks yang terjadi ini mengharuskan kita untuk fokus terhadap apa yang terpenting dalam aktivitas sehari-hari. globalisasi membawa banyak manfaat dan peluang, karena itu kita mesti belajar satu sama lain tanpa meninggalkan jati diri kita.

\section{d. Company}

Perusahaan harus memegang prinsip kejujuran, yang ditunjukkan dengan memberikan value yang sesuai kepada pelanggan dari produk-produk yang dihasilkan. penerapan nilai-nilai spiritual dalam perusahaan. Dengan menerapkan spiritual-based organization, mereka selalu menyampaikan pesan-pesan kepada bawahannya untuk menjadikan dunia sebagai tempat yang lebih baik dengan mengedepankan kerendahan hati dan kejujuran, bahkan ketika mereka telah menjadi pengusaha sukses.

\section{e. Segmentation}

$$
\text { Segmentasi adala seni }
$$
mengidentifikasi serta memanfaatkan peluangpeluang yang muncul di pasar. Segmentasi memungkinkan perusahaan untuk lebih fokus dalam mengalokasikan sumber daya. Dengan cara-cara yang kreatif dalam membagi-bagi pasar ke dalam beberapa segmen, perusahaan dapat menentukan di mana mereka harus memberikan pelayanan terbaik dan di mana mereka mempunyai keunggulan kompetitif paling besar.

\section{f. Targeting}

$$
\text { Targeting adalah strategi }
$$
mengalokasikan sumber daya perusahaan secara efektif, karena sumber daya yang dimiliki terbatas. Dengan menentukan target yang akan dibidik, usaha kita akan lebih terarah.

\section{g. Positioning}


Positioning adalah strategi untuk merebut posisi dibenak konsumen, sehingga strategi ini menyangkut bagaimana membangun kepercayaan, keyakinan, dan kompetensi bagi pelanggan. Dan untuk perusahaan berbasis syariah, membangun kepercayaan berarti menunjukkan komitmen bahwa perusahaan syariah itu menawarkan sesuatu yang lebih jika dibandingkan perusahaan non-syariah.

\section{h. Differentiation}

Diferensiasi didefinisikan sebagai tindakan merancang seperangkat perbedaan yang bermakna dalam tawaran perusahaan. Diferensiasi bisa berupa content (dimensi diferensiasi yang merujuk pada value yang ditawarkan kepada pelanggan), dan context (dimensi yang merujuk pada cara anda menawarkan produk).

\section{i. Marketing-Mix}

Marketing-mix yang elemenelemennya adalah product, price, place, dan promotion (4P). Product dan price adalah komponen dari tawaran (offers), sedangkan place dan promotion adalah komponen dari akses (access). Produk dan harga haruslah didasari dengan nilai kejujuran dan keadilan; sesuai dengan prinsip-prinsip syariah. Komponen akses (access) sangat berpengaruh terhadap bagaimana usaha dari perusahaan dalam menjual produk dan harganya. Promosi bagi perusahaan yang berlandaskan syariah haruslah menggambarkan secara riil apa yang ditawarkan dari produk-produk perusahaan tersebut.

\section{j. Selling}

Selling yang dimaksud di sini adalah bagaimana memaksimalkan kegiatan penjualan sehingga dapat menciptakan situasi yang win-win solution bagi si penjual dan pembeli. Dalam melakukan selling, perusahaan tidak hanya menyampaikan fiturfitur dari produk dan jasa yang ditawarkan saja, melainkan juga keuntungan dan bahkan solusi dari produk dan jasa tersebut.

\section{k. Brand}

Dalam pandangan syariah, Brand yang baik adalah yang mempunyai karakter yang kuat. Dan bagi perusahaan atau produk yang menerapkan syariah marketing, suatu brand juga harus mencerminkan karakter-karakter yang tidak bertentangan dengan prinsipprinsip syariah atau nilai-nilai spiritual. Beberapa karakter yang bisa dibangun untuk menunjukkan nilai spiritual ini bisa digambarkan dengan nilai kejujuran, keadilan, kemitraan, kebersamaan, keterbukaan, dan universalitas.

\section{l. Service}


Untuk menjadi perusahaan yang besar dan sustainable, perusahaan berbasis syariah marketing harus memperhatikan servis yang ditawarkan untuk menjaga kepuasan Stakeholders. Stakeholders yang dimaksud bukan Cuma konsumen saja tapi juga pemegang saham, pemerintah, dan para karyawan sendiri. "Every business is a service business".

\section{m. Process}

Proses mencerminkan tingkat quality, cost, dan delivery yang sering disingkat sebagai QCD. Proses dalam konteks kualitas adalah bagimana menciptakan proses yang mempunyai nilai lebih untuk konsumen. Proses dalam konteks cost adalah bagaimana menciptakan proses yang efisien yang tidak membutuhkan biaya yang banyak, tetapi kualitas terjamin. Sedangkan proses dalam konteks delivery adalah bagaimana proses pengiriman atau penyampaian produk atau servis yang ditawarkan perusahaan kepada konsumen.

\section{n. Scorecard}

Prinsip dalam syariah marketing adalah menciptakan value bagi para stakeholders-nya. Tiga stakeholders utama dari suatu perusahaan adalah pelanggan, karyawan, dan pemegang saham. Ketiga stakeholders itu sangat penting, karena mereka adalah orang-orang yang sangat berperan dalam menjalankan suatu usaha. Dalam menjaga keseimbangan ini, perusahaan 40 harus bisa menciptakan value yang unggul bagi ketiga stakeholders utama tersebut dengan ukuran bobot yang sama.

\section{o. Inspiration}

Inspirasi adalah tentang impian yang hendak dicapai yang akan membimbing perusahaan sepanjang perjalanannya untuk mewujudkan goals perusahaan tersebut. Maka, dalam perusahaan berbasis syariah marketing, penentuan visi dan misi tidak bisa terlepas dari makna syariah itu sendiri, dan tujuan akhir yang ingin dicapai. Tujuan akhir ini harus bersifat mulia, lebih dari sekedar keuntungan finansial semata.

\section{p. Culture}

Budaya perusahaan menggambarkan jati diri perusahaan tersebut. Hal ini tercermin dari nilai-nilai yang dianut oleh setiap individu di perusahaan dan perilakunya ketika menjalankan proses bisnisnya. Budaya perusahaan yang sehat adalah budaya yang diekspresikan oleh setiap karyawannya dengan hati terbuka dan sesuai dengan nilai-nilai etika. Berikut ini adalah beberapa budaya dasar dalam sebuah perusahaan berbasis syariah: Budayakan mengucapkan salam, murah hati, bersikap ramah, dan melayani, cara busana nuansa syariah, lingkungan kerja bersih. 
q. Institution

Prinsip yang terakhir adalah bagaimana membangun organisasi/institusi sesuai dengan prinsip-prinsip syariah. ${ }^{13}$

Dalam perusahaan syariah harus mempunyai sistem umpan balik yang bersifat transparan. Sistem umpan balik ini memeriksa tentang kepuasan akan terpenuhinya kebutuhan ketiga steak-holders utamanya. Transparansi berarti bahwa ketiga steak-holders utama itu harus mendapatkan informasi yang sejelas dan sejujur mungkin dari perusahaan. Pemasaran memainkan peran yang sangat penting dalam memenuhi kebutuhan konsumen, disamping pencapaian tujuan perusahaan. Dalam memenuhi tujuan ini, seorang pemasar muslim harus memastikan bahwa semua aspek kegiatan pemasaran, seperti perencanaan barang dan jasa, harga dan strategi distribusi, seperti halnya teknik promosi yang digunakan, haruslah sesuai dengan tuntunan al-Quran dan as-Sunnah.

\section{Etika Pemasaran dalam Perspektif Ekonomi} Syariah

Dewasa ini sering kita jumpai cara pemasaran yang tidak etis, curang dan tidak professional. Kiranya perlu dikaji bagaimana akhlak kita dalam kegiatan ekonomi secara

\footnotetext{
${ }^{13}$ Kertajaya, Hermawan dan M. Syakir Sula,
} Op, cit, h. 160-163 keseluruhan. Atau lebih khusus lagi akhlak dalam pemasaran kepada masyarakat dari sudut pandangan ekonomi Syariah. Kegiatan pemasaran seharusnya dikembalikan pada karakteristik yang sebenarnya. Yakni relegius, beretika dan menjunjung tinggi nilai-nilai kemanusiaan, inilah yang dinamakan merketing ekonomi syariah dan inilah konsep terbaik marketing untuk hari ini dan masa depan.

Prinsip marketing yang berakhlak seharusnya kita terapkan. Apalagi nilai-nilai akhlak, moral dan etika sudah diabaikan. Sangat dikhawatirkan bila menjadi kultur masyarakat. Perpektif pemasaran dalam ekonomi syariah adalah ekonomi Rabbani, realistis, humanis dan keseimbangan. Inilah yang membedakan sistem ekonomi Islam dengan sistem ekonomi konvensional.

Marketing menurut Islam memiliki nilai dan karakteristik yang menarik. Pemasaran syariah meyakini, perbuatan seseorang akan dimintai pertanggungjawabannya kelak. Selain itu, marketing syariah mengutamakan nilainilai akhlak dan etika moral dalam pelaksanaannya. Oleh karena itu, marketing syariah menjadi penting bagi para tenaga pemasaran untuk melakukan penetrasi pasar.

Dalam strategi pemasaran ekonomi syariah terdapat sembilan macam etika 
(akhlak) yang harus dimiliki seorang tenaga pemasaran. Yaitu :

1. Memiliki kepribadian spiritual (taqwa)

2. Berkepribadian baik dan simpatik (shiddiq)

3. Berlaku adil dalam berbisnis (al-'adl)

4. Melayani nasabah dengan rendah hati (khitmah)

5. Selalu menepati janji dan tidak curang (tahfif)

6. Jujur dan terpercaya (amanah)

7. Tidak suka berburuk sangka

8. Tidak suka menjelek-jelekkan

9. Tidak melakukan suap (risywah). ${ }^{14}$

Selain sembilan etika tersebut, marketer ekonomi syariah harus menghindari hal-hal sebagai berikut :

a. Tidak adil dalam penentuan tarif dan uang pertanggungan

b. Melakukan transaksi terhadap produk yang mengandung unsur maisar, gharar, dan riba maisar; transaksi tadlis

c. Khianat atau tidak menepati janji harga

e. Menjual barang hasil curian dan korupsi

f. Sering melakukan sumpah palsu atau sering berdusta

g. Melakukan penekanan dan pemaksaan terhadap pelanggan

h. Mempermainkan harga d. Menimbun barang untuk menaikkan

i. Mematikan pedagang kecil

j. Melakukan monopoli's rent seeking atau ikhtikar

k. Talaqqi rukban adalah menghadang atau mencegat kafilah dagang yang akan menjual barang dagangan mereka ke pasar, untuk membeli barang-barang dagangannya, sebelum mereka sampai di pasar sehingga mendapatkan harga yang murah.

1. Melakukan suap atau sogok untuk melancarkan kegiatan bisnis (riswah)

m. Melakukan tindakan korupsi ataupun money laundry. ${ }^{15}$

Jika para pemasar menjalankan aktivitas pemasaran yang diperintahkan dan meninggalkan larangan yang dilarang, pemasaran tersebut menjadi suatu aktivitas diperbolehkan dalam Islam. Oleh karena itu, dalam perspektif ekonomi syariah strategi pemasaran adalah segala aktivitas yang dijalankan dalam kegiatan bisnis berbentuk kegiatan penciptaan nilai (value creating activities) yang memungkinkan siapa pun yang melakukannya bertumbuh serta mendayagunakan kemanfaatannya yang dilandasi atas kejujuran, keadilan, keterbukaan, dan keikhlasan sesuai dengan proses yang berprinsip pada akad

${ }^{14} \mathrm{MA}$. Mannan, Ekonomi Islam "Teori \& Praktek" (Jakarta : Gema Insani Press, 1992), h. 369
${ }^{15} \mathrm{Ibid}$, h. 370 


\section{Jurnal Ilmu Ekonomi dan Bisnis Islam Vol.1 No. 1 Tahun 2019 \\ 100}

bermuamalah Islami atau perjanjian transaksi bisnis dalam Islam. ${ }^{16}$

\section{METODOLOGY}

Jenis merupakan asumsi fundemental dalam suatu penelitian guna memahami gejala dan masalah dari suatu obyek tertentu. Dalam penelitian ini, penulis menggunakan jenis deskriptif kualitatif, yakni memaparkan secara praktis tentang obyek yang diteliti beserta hasil penelitian penulis dengan terlebih dahulu melakukan analisis dan penetapan nilai, sesuai denga stadar-standar buku dalam jenis deskriptif kualitatif. $^{17}$ Disini penulis melakukan analisis data dengan memberi pemaparan gambaran mengenai situasi yang diteliti, hakikat pemaparan adalah seperti orang yan merajut, setiap bagian ditelaah satu demi satu, dengan menjawab pertanyaan apa, mengapa dan bagimana suatu penomena itu terjadi dalam konteks lingkungannya. Objektivitas pemaparan harus di jaga agar subjektivitas penentu dalam membuat interpretasi pada penomena atau gejala-gejala yang bersifat alami dan dilakukan untuk menghasilkan data yang efektif sesuai dengan kejadiankejadian yang terjadi dilokasi penelitian sarta

\footnotetext{
${ }^{16} \mathrm{M}$. Ismail Yusanto dan M.K. Widjajakusuma, h. 95

${ }^{17}$ Suharsini Arikunto, Prosedur Penelitian Ilmiyah : Suatu Pendekatan Praktek, (Jakarta: PT. Rineka Cipta, 1993), h. 209
}

tidak memerlukan hipotesis yang sifatnya menduga-duga.

Seluruh data yang telah dikumpulkan akan diolah dan diseleksi berdasarkan prinsip pendekatan kualitatif. Hal ini dimaksudkan untuk memperoleh data yang bermutu, sebagai mana dikemukakan oleh Lexi J Maleong" data yang manual berwujud kata-kata dan angka itu dikumpulkan dengan berbagai macam cara (observasi, angket, wawancara, dokumen, pitadukumen) tetapi analisis kualitatif tetap menggunakan angkaangka. Biasanya disusun dalam teks yang di perluas" 18

Dalam pelaksanaan dilokasi penelitian, penulis menentukan informan yang akan diteliti dan ditelusuri secara mendalam supaya data yang diperoleh betul-betul valid dan dapat dipertangung jawabkan secara ilmiah yaitu dengan mengunakan teknik observasi, wawancara mendalam, dan data dari berbagai dokumen tertulis .

Setelah data dan keterangan berhasil dikumpulkan peneliti, maka langkah selanjutnya adalah menganalisis beberapa data yang diperoleh dalam bentuk analisis deskriptif dengan mengunakan beberapa tekhnik analisis data antara lain reduksi data, verifikasi data, pengecekan keabsahan data, melakukan tringulasi untuk memeperoleh tingkat kevaliditan yang tinggi.

\footnotetext{
${ }^{18}$ Lexy J. Maleong, Metodologi Penelitian Kualitatif, (Bandung : Remaja Rosdakarya, 2002) h. 3
} 


\section{Jurnal IImu Ekonomi dan Bisnis Islam Vol.1 No. 1 Tahun 2019}

\section{HASIL DAN PEMBAHASAN}

\subsection{Gambaran Lokasi Penelitian}

Dinas Perindustrian, Perdagangan, Koperasi dan UKM Kota Palu awalnya bernama Kantor Departemen Perindustrian Kota Administratif Palu. Kantor Kota Administratif Palu ini berdiri sejak Tahun 1984. Kantor Perindustrian merupakan satusatunya kantor departemen vertikal yang ada di Kota Palu pada saat itu. Seiring dengan perkembangan pembangunan sektor industri, Kantor Departemen Perindustrian Kota Palu beberapa kali mengalami perubahan struktur organisasi, kemudian tahun 1996 terjadi penggabungan dua departemen yaitu antara Departemen Perindustrian dan Perdagangan.

Sesuai dengan Keputusan Menteri Perindustrian dan Perdagangan Nomor : 84/MPP/Kep/4/96 Tanggal 15 April 1996, maka kantor Departemen Perindustrian Kota Administratif Palu berubah nama menjadi Kantor Departemen Perindustrian dan Perdagangan Kota Palu. Kemudian Tahun 1999 Menteri Perindustrian dan Perdagangan mengeluarkan keputusan Nomor: 394/MPP/Kep/8/1999 tentang Perubahan Struktur Organisasi Departemen Perindustrian dan Perdagangan Seluruh Indonesia. Hal ini dimaksudkan untuk lebih memaksimalkan pembinaan sektor industri dan perdagangan di daerah.
Dengan adanya UU No. 22 Tahun 1999 tentang Pelaksanaan Pemerintah Daerah atau yang telah dikenal dengan daerah otonom, maka Departemen Perindustrian dan Perdagangan menyerahkan 3 P (Personalia, Pembiayaan, Prasarana) kepada pemerintah Kota Palu, dan pada Tahun 2000 lahirlah peraturan daerah Nomor : 32 Tahun 2000 tentang kelembagaan Dinas Perindustrian Perdagangan dan Koperasi Kota Palu dengan Kepala Dinas yang pertama Drs. Irwan Parampasi.

Pada Tahun 2006 terjadi reformasi birokrasi di lingkungan pemerintah daerah dengan diterbitkannya Peraturan pemerintah Nomor 8 Tahun 2006, namun tidak ada perubahan struktur kelembagaan pada Dinas Perindustrian, Perdagangan dan Koperasi Kota Palu. Pada Tahun 2009, dengan terbitnya Peraturan Pemerintah Nomor 41 Tahun 2007, terjadi perubahan nama lembaga menjadi Dinas Perindustrian, Perdagangan dan Koperasi Kota Palu. Perubahan nama lembaga diikuti oleh perubahan struktur itu merujuk pada Peraturan Daerah Nomor 5 Tahun 2008 tentang Struktur Organisasi Kelembagaan Dinas Daerah Kota Palu.

\subsection{Strategi Pemasaran Produk Khas daerah \\ Kota Palu merupakan salah satu daerah yang memiliki potensi dan daya saing yang kuat melalui produk-produk khas unggulan}




\section{Jurnal IImu Ekonomi dan Bisnis Islam Vol.1 No. 1 Tahun 2019}

102

daerah terbaiknya seperti industri anyaman rotan. Pemerintah Kota Palu melalui Dinas Perindustrian, Perdagangan, Koperasi dan UKM Kota Palu terus berupaya mengoptimalkan potensi daerah melalui pembinaan industri kecil dan menengah (IKM) melalui produk-produk unggulan khas daerah terbaiknya, agar dapat terus tumbuh dan berkembang menjadi kegiatan usaha yang menguntungkan, sehingga dapat mendorong peningkatan kesejahteraan masyarakat.

UKM Berdasarkan Undang Undang Nomor 20 Tahun 2008 tentang UMKM (Usaha Menengah Kecil dan Mikro) adalah usaha produktif milik orang perorangan dan / atau badan usaha perorangan yang memenuhi kriteria UKM sebagaimana diatur dalam Undang-Undang ini. UKM merupakan kegiatan usaha yang dapat memperluas lapangan pekerjaan serta memberikan pelayanan ekonomi secara luas kepada masyarakat dan dapat berperan dalam proses pemerataan dan peningkatan pendapatan masyarakat, mendorong pertumbuhan ekonomi, serta berperan mewujudkan stabilitas nasional.

Ciri-ciri UKM yaitu

a. Jenis barang usahanya tidak tetap,dapat berganti pada periode tertentu;

b. Tempat usahanya tidak selalu menetap, dapat berubah sewaktu-waktu; c. Belum melaksanakan administrasi keuangan yang sederhana dan tidak memisahkan antara keuangan keluarga dengan keuangan usaha; Sumber daya manusia (pengusaha) belum memiliki jiwa enterpreuner yang memadai;

d. Tingkat pendidikan rata-rata relatif rendah;

e. Pada umumnya belum akses ke perbankan, namun sebagian dari mereka sudah akses ke lembaga keuangan non bank;

f. Umumnya tidak mempunyai izin usaha atau prasyaratan legalitas lainnya termasuk Nomor Pokok Wajib Pajak (NPWP)

Adapun jenis-jenis produk khas unggulan kota palu yaitu :

a. Kerajinan tangan

- Kerajianan rotan berupa perabotan dan perlengkapan rumah tangga

- Kerajinan kayu hitam

b. Kuliner

- Bawang goreng

- Abon ikan

- Kripik pisang dan umbi-umbian

- Dodol durian

- Coklat

Tabel 1. Data Industri Menurut Kategori 
Jurnal IImu Ekonomi dan Bisnis Islam Vol.1 No. 1 Tahun 2019

103

\begin{tabular}{|c|c|c|c|c|}
\hline No & Klasifikasi & $\begin{array}{l}\text { Unit } \\
\text { Usaha }\end{array}$ & Tk & $\begin{array}{r}\text { Investasi } \\
\text { (Rp. 000) }\end{array}$ \\
\hline 1 & Mikro & $8^{11}$ & 923 & 3.126 .420 \\
\hline 2 & Kecil & $6^{10}$ & 1.540 & 4.866 .260 \\
\hline 3 & $\begin{array}{ll} & \text { Meneng } \\
\text { ah } & \\
\end{array}$ & 16 & 664 & 50.159 .600 \\
\hline & Jumlah & $0^{24}$ & 3.127 & 58.152 .280 \\
\hline
\end{tabular}

Perkembangan dan pertumbuhan produk-produk unggulan khas daerah Kota Palu, tidak terlepas dari strategi pemasaran yang dijalankan oleh Pemerintah Kota Palu melalui Dinas Perindustrian, Perdagangan, Koperasi dan UKM Kota Palu yang berkelanjutan sehingga mampu memberikan kontribusi signifikan dalam memperkuat perekonomian Kota Palu karena strategi pemasaran yang tepat serta terarah akan menjadi kunci kesuksesan bagi pemasaran suatu produk terutama produk-produk khas daerah.

Adapun strategi pemasaran produk khas daerah oleh Dinas Perindustrian, Perdagangan, Koperasi dan UKM Kota Palu dalam perspektif ekonomi syariah, sebagaimana yang di jelaskan oleh Desinanto Lebang, S.E adalah sebagai berikut

Adapun strategi pemasaran produk khas daerah oleh Dinas Perindustrian Perdagangan dan Koperasi Kota Palu dalam perspektif ekonomi syariah adalah ikut serta dalam berbagai pameran baik itu pameran yang di adakan di Kota Palu maupun pameran dalam skala nasional. ${ }^{19}$

Dari penjelasan di atas dapat dipahami bahwa strategi pemasaran produk khas daerah oleh Dinas Perindustrian, Perdagangan, Koperasi dan UKM Kota Palu (Dalam perspektif ekonomi syariah), adalah ikut serta dalam berbagai pameran baik itu pameran yang di adakan di Kota Palu maupun pameran dalam skala nasional.

Hal senada juga di ungkapkan oleh Sarufuddin, ST sebagai berikut :

Selain ikut serta serta dalam berbagai pameran, kami juga ikut nimbrung untuk mempromosikan barang-barang produk khas daerah Kota Palu di setiap acaraacara besar yang diadakan oleh Pemerintah Daerah Kota Palu maupun di luar daerah Kota Palu. ${ }^{20}$

Dari ungkapan di atas dapat diketahui bahwa strategi pemasaran produk khas daerah oleh Dinas Perindustrian, Perdagangan, Koperasi dan UKM Kota Palu dalam perspektif ekonomi syariah adalah ikut nimbrung untuk mempromosikan barang-barang produk khas daerah Kota Palu di setiap acara-acara besar yang diadakan oleh Pemerintah Daerah Kota Palu maupun di luar daerah Kota Palu.

\footnotetext{
${ }^{19}$ Desinanto Lebang, Kasi Retribusi Pasar Dinas Perindustrian, Perdagangan, Koperasi dan UKM Kota Palu, "Wawancara" pada tanggal 28 Juli 2016

${ }^{20}$ Sarifuddin, ST, Staf Dinas Perindustrian, Perdagangan, Koperasi dan UKM Kota Palu "Wawancara" pada tanggal 1 Agustus 2016
} 


\section{Jurnal Ilmu Ekonomi dan Bisnis Islam Vol.1 No. 1 Tahun 2019 \\ 104}

Anna Krisna juga menjelaskan tetntang strategi pemasaran produk khas daerah oleh Dinas Perindustrian, Perdagangan, Koperasi dan UKM Kota Palu (Dalam perspektif ekonomi syariah), sebagai berikut :

Salah satu strategi kami dalam memasarkan produk khas daerah Kota Palu adalah melalui puskum kreatif, di mana produk khas daerah di pasarkan melalui media elektronik dengan tujuan agar seluruh lapisan masyarakat kususnya daerah Sulawesi Tengah tahu tentang produk-produk unggulan khas Daerah Kota palu dan agar seluruh pasar dan pelaku bisnis bisa tersentuh baik pasar dan pelaku bisnis lokal maupun pasar dan pelaku bisnis di daerah-daerah luar. ${ }^{21}$

Dari penjelasan di atas dapat dipahami bahwa strategi pemasaran produk khas daerah oleh Dinas Perindustrian, Perdagangan, Koperasi dan UKM Kota Palu (Dalam perspektif ekonomi syariah), adalah melalui puskum kreatif, di mana produk khas daerah di pasarkan melalui media elektronik dengan tujuan agar seluruh lapisan masyarakat Sulawesi Tengah tahu tentang produk-produk khas Daerah Kota palu dan agar seluruh pasar dan pelaku bisnis bisa tersentuh baik pasar dan pelaku bisnis lokal maupun pasar dan pelaku bisnis di daerahdaerah luar.

Fahrul Azis, Kepala Seksi Promosi dan Kemitraan Dinas Perindustrian,

\footnotetext{
${ }^{21}$ Anna Krisna, Staf Dinas Perindustrian, Perdagangan, Koperasi dan UKM Kota Palu "Wawancara" pada tanggal 8 Agustus 2016
}

Perdagangan, Koperasi dan UKM Kota Palu juga menambahkan sebagai berikut :

Strategi-strategi kami dalam memasarkan produk khas daerah Kota Palu diantaranya adalah dengan mempromosikan dan menjalin kemitraan dengan usaha-usaha kecil menengah yang ada di Kota palu, bahkan kami terjun langsung ke setiap Dinas-Dinas yang ada di pemerintah Kota palu untuk mengunakan produk khas daerah Kota Palu sebagai percontohan bagi lembagalembaga yang lainnya dan masyarakat Kota Palu. $^{22}$

Dari penjelasan di atas dapat diketahui bahwa strategi pemasaran produk khas daerah oleh Dinas Perindustrian, Perdagangan, Koperasi dan UKM Kota Palu adalah dengan mempromosikan dan menjalin kemitraan dengan usaha-usaha kecil menengah yang ada di Kota palu dan terjun langsung ke setiap Dinas-Dinas yang ada di pemerintah Kota Palu untuk mengunakan produk khas daerah Kota Palu sebagai percontohan bagi lembaga-lembaga yang lainnya dan masyarakat Kota Palu.

\subsection{Kendala-Kendala}

Setiap kegiatan tentunya tidak akan berjalan dengan mulus dan lancar, sebab segala sesuatu yang dilakukan untuk dapat

\footnotetext{
${ }^{22}$ Fahrul Azis, Kepala Seksi Promosi dan Kemitraan Dinas Perindustrian, Perdagangan, Koperasi dan UKM Kota Palu, "Wawancara" pada tanggal 4 Agustus 2016
} 


\section{Jurnal IImu Ekonomi dan Bisnis Islam Vol.1 No. 1 Tahun 2019 \\ 105}

mencapai suatu tujuan tentu saja akan menghadapi rintangan dan hambatan, termasuk strategi pemasaran produk khas daerah oleh Dinas Perindustrian Perdagangan dan Koperasi Kota Palu (Dalam perspektif ekonomi syariah).

Adapun kendala-kendala yang dihadapi oleh Dinas Perindustrian, Perdagangan, Koperasi dan UKM Kota Palu dalam dalam memasarkan produk khas daerah Kota Palu (Dalam perspektif ekonomi syariah), adalah sebagai berikut :

1. Belum mempunyai outlet sendiri yang di sediakan oleh pemerintah. Sebagaimana yang dijelaskan oleh Etik Nuraini sebagai berikut :

Adapun kendala-kendala yang dihadapi oleh Dinas Perindustrian, Perdagangan, Koperasi dan UKM Kota Palu dalam memasarkan produk-produk khas daerah Kota Palu adalah belum mempunyai outlet sendiri yang di sediakan oleh pemerintah sehinnga dalam memasarkan produk-produk khas daerah Kota Palu tidak menetap sehinnga dalam memasarkannya kepada masyarakat hasilnya tidak maksimal. ${ }^{23}$

Dari penjelasan di atas dapat diketahui bahwa kendala-kendala yang dihadapi oleh Dinas Perindustrian, Perdagangan, Koperasi dan UKM Kota Palu dalam

${ }^{23}$ Etik Nuraini, Kasi Usaha Industri Dinas Perindustrian, Perdagangan, Koperasi dan UKM Kota Palu, "Wawancara" pada tanggal 8 Agustus 2016 memasarkan produk-produk khas daerah Kota Palu adalah belum mempunyai outlet sendiri yang di sediakan oleh pemerintah.

2. Khusus Kota Palu belum ada sentra usaha kecil menengah (UKM) yang berpusat pada satu tempat untuk satu jenis produk.

Sebagaimana yang disampaikan oleh informan sebagai berikut :

Salah satu kendala-kendala yang dihadapi oleh Dinas Perindustrian, Perdagangan, Koperasi dan UKM Kota Palu dalam memasarkan produk-produk khas daerah Kota Palu adalah belum adanya sentral usaha kecil menengah (UKM) yang berpusat pada satu tempat untuk satu jenis produk sehingga dalam memasarkannya berbaur dengan produkproduk lain yang sudah modern. ${ }^{24}$

Dari penyampaian di atas dapat dipahami bahwa kendala-kendala yang dihadapi oleh Dinas Perindustrian, Perdagangan, Koperasi dan UKM Kota Palu dalam memasarkan produk-produk khas daerah Kota Palu adalah belum adanya sentral usaha kecil menengah (UKM) yang berpusat pada satu tempat untuk satu jenis produk.

3. Kurangnya minat masyarakat terhadap produk-produk lokal.

\footnotetext{
${ }^{24}$ Jermia Tapussa, S.Sos, Kabid Industri Aneka Dinas Perindustrian, Perdagangan, Koperasi dan UKM Kota Palu, "Wawancara" pada tanggal 15Agustus 2016
} 


\section{Jurnal Ilmu Ekonomi dan Bisnis Islam Vol.1 No. 1 Tahun 2019 \\ 106}

Sebagaimana yang diungkapkan oleh Yudhi

R. Firman, Kepala Bidang Pasar sebagai berikut :

Kendala yang paling besar yang dihadapi oleh Dinas Perindustrian, Perdagangan, Koperasi dan UKM Kota Palu dalam memasarkan produk-produk khas daerah Kota Palu adalah kurangnya minat masyarakat terhadap produk-produk lokal, mereka lebih tertarik kepada produk-produk yang yang dari luar walaupun dari segi kualitas produkproduk lokal yang kita miliki tidak kalah bagusnya. ${ }^{25}$

Dari ungkapan di atas dapat dipahami bahwa kendala-kendala yang dihadapi oleh Dinas Perindustrian, Perdagangan, Koperasi dan UKM Kota Palu dalam memasarkan produk-produk khas daerah Kota Palu adalah kurangnya minat masyarakat terhadap produk-produk lokal.

\section{PENUTUP}

Berdasarkan hasil penelitian yang telah diuraikan sebelumnya, maka penulis dapat mengambil kesimpulan sebagai berikut:

1. Strategi pemasaran produk khas daerah oleh Dinas Perindustrian, Perdagangan, Koperasi dan UKM Kota Palu (Dalam Perspektif Ekonomi Syariah), adalah ikut serta dalam berbagai pameran baik itu pameran yang di adakan di Kota Palu maupun pameran dalam skala nasional, ikut nimbrung untuk mempromosikan barang-barang produk khas daerah Kota Palu di setiap acara-acara besar yang diadakan oleh Pemerintah Daerah Kota Palu maupun di luar daerah Kota Palu, melalui puskum kreatif, di mana produk khas daerah di pasarkan melalui media elektronik dan dengan mempromosikan dan menjalin kemitraan dengan usahausaha kecil menengah yang ada di Kota palu serta terjun langsung ke setiap Dinas-Dinas yang ada di pemerintah Kota Palu , namun tetap berada dalam ketentuan syari'ah sehingga pertumbuhan ekonomi dan kesejahtraan daerah menjadi berkah tersendiri bagi masyarakat kota palu.

2. Kendala-kendala yang dihadapi oleh Dinas Perindustrian, Perdagangan, Koperasi dan UKM Kota Palu dalam dalam memasarkan produk khas daerah Kota Palu (Dalam perspektif ekonomi syariah), adalah belum mempunyai outlet sendiri yang di sediakan oleh pemerintah, belum adanya sentral usaha kecil menengah (UKM) yang berpusat pada satu tempat untuk satu jenis produk dan kurangnya minat masyarakat terhadap produk-produk lokal.
${ }^{25}$ Yudhi R. Firman, Kabid Pasar Dinas Perindustrian, Perdagangan, Koperasi dan UKM Kota Palu, "Wawancara" pada tanggal 18 Agustus 2016 


\section{DAFTAR PUSTAKA}

Departemen Agama RI, Al-qur'an Dan Terjemahannya, Surabaya : Duta Ilmu, 2005

Arikunto, Suharsini, Prosedur Penelitian Ilmiyah : Suatu Pendekatan Praktek, Jakarta: PT. Rineka Cipta, 1993

Ancella Hermawati Anitawati, Manajemen pemasaran , (Jakarta : salemba empat, 1995

Aswar Adiwarman Karim, Ekonomi Islam Suatu Kajian Kontemporer, (Jakarta: Gema Insani Press, 2001

Elqomi Ahmadi, Dasar Marketing Syari'ah, (Bandung : Madani Prima, 2008

Ganara Thorik dan Utus Hardjono Sudibyo, Marketing Muhammad, (Bandung : Madani Prima, 2007),

Ismail M. Yusanto dan M.K. Widjajakusuma. Menggagas Bisnis Islami. (Jakarta : Gema Insani Press, 2002

J. William Stanton, Prinsip Pemasaran, (Jakarta : Erlangga, 1986

Kartajaya Hermawan dan Muhammad Syakir Sula: Syariah Marketing, MarkPlus \& Co, (Bandung : Mizan Pustaka, 2006

Kartono, Kartini, Pengantar Metodologi Riset Sosial, Bandung: CV. Bandar Maju, 1996

Kotler Philip, dan Gary Armstrong, Prinsipprinsip pemasaran, (Jakarta : Erlangga, 2005
Mannan MA., Ekonomi Islam "Teori \& Praktek” (Jakarta : Gema Insani Press, 1992

Mardani, Hukum Ekonomi Syariah di Indonesia, (Bandung : PT. Refika Aditama, 2011

Miles, B Mathew dan A. Michael Huberman, Qualitative Data Analysis, di terjemahkan oleh Tjejep Rohidi dengan judul Analisis Data Kualitatif Buku Tentang MetodeMetode baru Cet I ; Jakarta; UIPerss, 1992

Muflih Muhammad, Perilaku Konsumen dalam Perspektif Ilmu Ekonomi Islam. (Jakarta: PT. Raja Grafindo Persada, 2006

Moleong J. Lexy. Metodologi Penelitian Kualitatif. Bandung: Remaja Rosdakarya, 2002

Narbuko Cholid dan Achmadi Abu, Metodologi Penelitian, Cet.IV; Jakarta: PT. Bumi Aksara, 2002

Nasution, S., Metode Research Penelitian Ilmiah, Cet, VII; Jakarta: Bumi Aksara, 1997

Rama Tri K.,Kamus Lengkap Bahasa Indonesia, Surabaya : Karya Agung, 1998

Surakhman, Winarno, Dasar Dan Tehnik Research Pengantar Meteologi Ilmiyah, Ed, VI; Bandung, 1997

Umar, Husen, Metode Penelitian untuk Skripsi dan Tesis Bisnis, Cet.IV; Jakarta: PT. Raja Grafindo Persada, 2001. 